\title{
Preparation and Characterization of Adsorbent Carbon Derived from Cocus nucifera at an Elevated Temperature
}

\author{
R. Sangeetha Piriya ${ }^{1 *}$, R.M. Jayabalakrishnan ${ }^{2}$, M. Maheswari ${ }^{1}$ and K. Venkatesan ${ }^{2}$ \\ ${ }^{1}$ Department of Environmental Sciences, Tamil Nadu Agricultural University, \\ Coimbatore, 641 003, India \\ ${ }^{2}$ Coconut Research Station, Tamil Nadu Agricultural University, Aliyarnagar, 642 101, India \\ *Corresponding author
}

\section{A B S T R A C T}

\begin{tabular}{|c|c|}
\hline Keywords & \multirow{4}{*}{$\begin{array}{l}\text { Coconut shells were used as a raw material to produce powdered adsorbent carbon of size } \\
\text { less than } 2 \mathrm{~mm} \text {. The } \mathrm{pH} \text {, electrical conductivity, proximate analysis (moisture content, } \\
\text { volatile matter, ash content and fixed carbon content), ultimate analysis (Carbon, } \\
\text { Hydrogen, Nitrogen and Sulphur content), bulk density, particle density, total organic } \\
\text { carbon and yield (percentage recovery) were analyzed as per the standard procedures. The } \\
\text { raw material of about } 20 \mathrm{~kg} \text { was converted to adsorbent carbon of about } 6 \mathrm{~kg} \text { through } \\
\text { thermochemical conversion in the absence of oxygen. The produced carbon was rich in } \\
\text { carbon ( } 91.27 \text { percentile), with least } 1.50 \text { percentile of ash content and this attribute figures } \\
\text { out the nature of material with its lower inorganic content and high fixed carbon content } \\
\text { which is ingrained to its organic nature. }\end{array}$} \\
\hline $\begin{array}{l}\text { Coconut shells, } \\
\text { Adsorbent carbon, } \\
\text { Pyrolysis, } \\
\text { Carbonization }\end{array}$ & \\
\hline Article Info & \\
\hline $\begin{array}{l}\text { Accepted: } \\
\text { 12 April } 2019 \\
\text { Available Online: } \\
\text { 10 May } 2019\end{array}$ & \\
\hline
\end{tabular}

\section{Introduction}

Carbon particles/fibres own exceptional properties. Agricultural products are rich in carbon contents and are budding source for carbon production. They are cheap, easily available and renewable. These factors make it to be more potent than any other material. Thermochemical processes that converts the carbonaceous materials to char (fixed carbon), with enhanced surface area and adsorptive power is said to be activated carbon and the process, carbonization(Bello, 2016).
The use of activated carbon has gained attention on an industrial scale, which includes the purification of gases, removal of organic pollutants from water, as catalysts in some catalytic processes and in the electrochemical devices as electrode materials. Although the activated carbon was the first recognized adsorbent and is still used in industry, the development of appropriate methods to make them and the understanding of their porous structure still continue. Various carbon rich materials are being used to produce activated carbon, such as sugarcane bagasse, nutshells, forest residues, tobacco. The availability and abundance of 
agricultural residues make them a good source of raw materials. The coconut shells have no little or no economic value and their disposal is not only costly but cause environmental problems ( $\mathrm{Li}$ et al., 2008). Since, the waste generated by the agricultural sector is either left with no use, therefore the concept of utilizing it in an effective manner can be a great part of reducing its quantity. The conversion of coconut shell to activated carbon would add a value to these produces and suits to be the cheap and best alternative for other carbon sources.

Adsorbent Carbon from Cocos nucifera (Coconut shell) influenced by raw material and production of coconut shell based activated carbon is limited to South India mainly because of concentration of coconut production. The town Pollachi in the shadows of Western Ghats has ambient conditions for the growth of coconut trees. One of the major challenges associated with adsorption using activated carbon is its cost effectiveness. Researches in the recent past have mainly focused on the preparation of the activated carbon from agricultural waste materials as an alternative for the commercial activated carbon (Horsfall, 2007).

\section{Materials and Methods}

\section{Collection of raw materials}

Cocos nucifera (Coconut) shells was collected from various parts of Pollachi as a raw material for the production of adsorbent carbon and then pretreatment was carried out before producing activated carbon.

\section{Pre-treatment of raw materials}

The coconut shells were sun dried for about 8-12 hrs for the complete removal of moisture content present in it. The dried shells were then sorted and packed in zip lock cover for further process. This material stands to be the precursor for the further activation under the exposure of various atmospheric conditions.

\section{Carbonization method}

The biochar production was carried out in a slow pyrolysis unit as shown in figure 1, where it is a double walled cylindrical chamber with two hollow portions covered with charcoal of shells in the smaller part and dried Coconut shells of about $20 \mathrm{~kg}$ in the bigger part. Above all, there exist a narrow chimney along with the lid which helps in removing the exhaust and preventing the formation of ash due to excess heat inside. This setup constitutes a pyrolytic chamber wherein a huge biomass quantity can be converted to biochar under high temperature. The dried shells were then exposed to $450^{\circ} \mathrm{C}$ in the chamber resulting in carbonized shells called biochar with a high amount of fixed carbon. The pyrolysis was carried out continuously for 2 hours without any disturbance and removal of chimney. After completion of the process, when the unit was cooled to its normal temperature, the chimney was removed and the lustrous and good conditioned shells of about $6 \mathrm{~kg}$ were removed from it. There was $30 \%$ yield recovery from $20 \mathrm{~kg}$ of Coconut shells. The adsorbent carbon was broken into small pieces, crushed using a wooden hammer, sieved to obtain a size less than $2 \mathrm{~mm}$ (Fig. 2) and stored in hot air oven at $60^{\circ} \mathrm{C}$ for studying its characteristics.

\section{Results and Discussion}

The adsorbent carbon produced is needed to be studied for understanding the potential powers and stability when compared to other adsorbents. The initial characteristics/ parameters such as $\mathrm{pH}$, electrical conductivity, proximate analysis (moisture content, volatile matter, ash content and fixed carbon content), ultimate analysis (Carbon, Hydrogen, Nitrogen and Sulphur content), 
bulk density, particle density, total organic carbon and yield (percentage recovery) were analyzed as per the standard procedures and shown in table 1 .

\section{Carbonization}

For adsorbent carbon to have desired properties, the temperature should be maintained where carbonization takes place. The carbonization influences the molecular architecture of carbonized material. Disturbances in the elementary microcrystalline structure by the presence of imperfect or partially burnt off carbon layers changes the arrangement of electron cloud in the carbon skeleton. As a result, unpaired electrons appear and the condition influences the adsorption properties of the activated carbon, especially for polar and polarisable substances (Ekpete et al., 2011). The temperature of $450^{\circ} \mathrm{C}$ was chosen for the production of carbonized shells. It was observed that if the temperature increases, there is increase in ash content and huge lose of carbon was noticed.

\section{pH and EC}

The $\mathrm{pH}$ and $\mathrm{EC}$ of material was analyzed using $\mathrm{pH}$ meter (M/s. Elico, India) and Conductivity meter (M/s. Elico, India) was found to be 8.79 and $1.70 \mathrm{dS} \mathrm{m} \mathrm{m}^{-1}$, respectively. Okieimen (2007) and Ahmedna (2007) have reported that $\mathrm{pH}$ in range of $6-8$ is acceptable for carbon in its application purpose. The measured $\mathrm{pH}$ is slightly higher than the above said value, which is acceptable.

\section{Bulk density and particle density}

The bulk density and particle density are physical properties which determine its filterability character and it was found to be $0.51 \mathrm{~g} \mathrm{~cm}^{-3}$ and $0.06 \mathrm{~g} \mathrm{~cm}^{-3}$, respectively. The bulk density determines the mass of carbon that can be contained in a filter of given solids capacity and the amount of treated liquid that can be retained by the filter cake (Okieimen (2000). It was determined by Okieimen (2000) that generally $0.5 \mathrm{~g} / \mathrm{cc}$ is adequate in sugar decolourization, which states the produced adsorbent can be used as filter.

\section{Total organic carbon}

The total organic carbon was found to be $86.22 \%$ which indicates its higher carbon content. The Coconut shells are biodegradable and organic in nature, upon carbonization the shells are thermo-chemically converted to carbon, with less ash and moisture content.

Proximate analysis (moisture content, volatile matter, ash content and fixed carbon content)

The proximate analysis results were given in table 2. The moisture content has no effect on adsorptive power unless it increases the weight and hinders the porous nature. The results indicate that $1.50 \%$ of moisture content (by mass) was found in the produced adsorbent carbon because of complete removal of moisture through evaporation and only $1.35 \%$ of ash content (on dry basis, by mass) was found in it which means almost all the material was converted to carbon. The ash content affects the adsorbent by reducing its overall activity and efficiency of reactivation. Lower the ash content better is the adsorbent quality and it indicates smaller particle density which means the material is suitable for adsorbent in any of the column or fixed bed reactor (Ekpete et al., 2011).

\section{Ultimate analysis (C, H, N, \& S)}

The ultimate analysis results were given in table 3 which indicates that carbonization temperature manipulated the properties of 
adsorbent with a higher Carbon percentage of about $91.27 \%$ followed with $3.12 \%$
Nitrogen, $0.48 \%$ Hydrogen and with zero percentage of Sulphur content.

Table.1 Characteristics of Adsorbent Carbon from coconut shells prepared at $450^{\circ} \mathrm{C}$

\begin{tabular}{|c|l|c|}
\hline S.No & \multicolumn{1}{|c|}{ Property } & Coconut shell \\
\hline $\mathbf{1}$ & $\mathrm{pH}$ & 8.79 \\
\hline $\mathbf{2}$ & $\mathrm{EC}\left(\mathrm{dS} \mathrm{m}^{-1}\right)$ & 1.70 \\
\hline $\mathbf{3}$ & Bulk density $\left(\mathrm{g} \mathrm{cm}^{-3}\right)$ & 0.51 \\
\hline $\mathbf{4}$ & Particle density $\left(\mathrm{g} \mathrm{cm}^{-3}\right)$ & 0.06 \\
\hline $\mathbf{5}$ & Total organic carbon $(\%)$ & 86.22 \\
\hline $\mathbf{6}$ & Yield $(\%)$ & 30 \\
\hline
\end{tabular}

Table.2 Proximate analysis

\begin{tabular}{|c|l|c|}
\hline S.No & \multicolumn{1}{|c|}{ Property } & Coconut shell \\
\hline $\mathbf{1}$ & Moisture content (\%) & 1.50 \\
\hline $\mathbf{2}$ & Volatile matter (\%) & 79.57 \\
\hline $\mathbf{3}$ & Ash content (\%) & 1.35 \\
\hline $\mathbf{4}$ & Fixed Carbon (\%) & 17.58 \\
\hline
\end{tabular}

Table.3 Ultimate analysis

\begin{tabular}{|c|l|c|}
\hline S.No & \multicolumn{1}{|c|}{ Property } & Coconut shell \\
\hline $\mathbf{1}$ & Carbon (\%) & 91.27 \\
\hline $\mathbf{2}$ & Hydrogen $(\%)$ & 3.12 \\
\hline $\mathbf{3}$ & Nitrogen $(\%)$ & 0.48 \\
\hline $\mathbf{4}$ & Sulphur (\%) & 0 \\
\hline
\end{tabular}

Figure.1 Pyrolysis unit

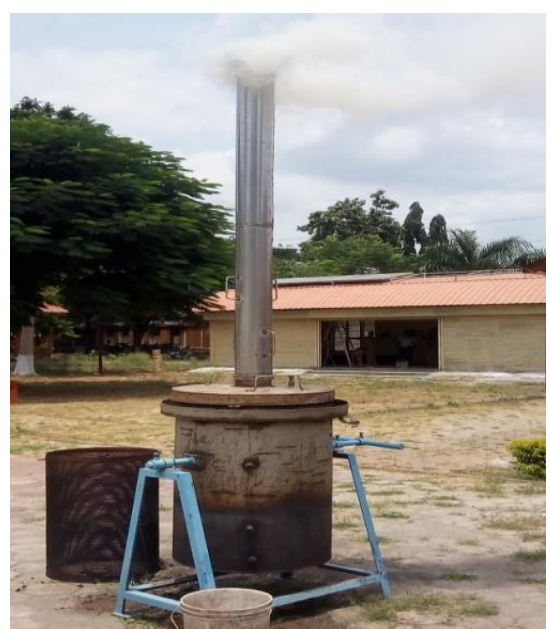

Figure.2 Adsorbent prepared through carbonization process 


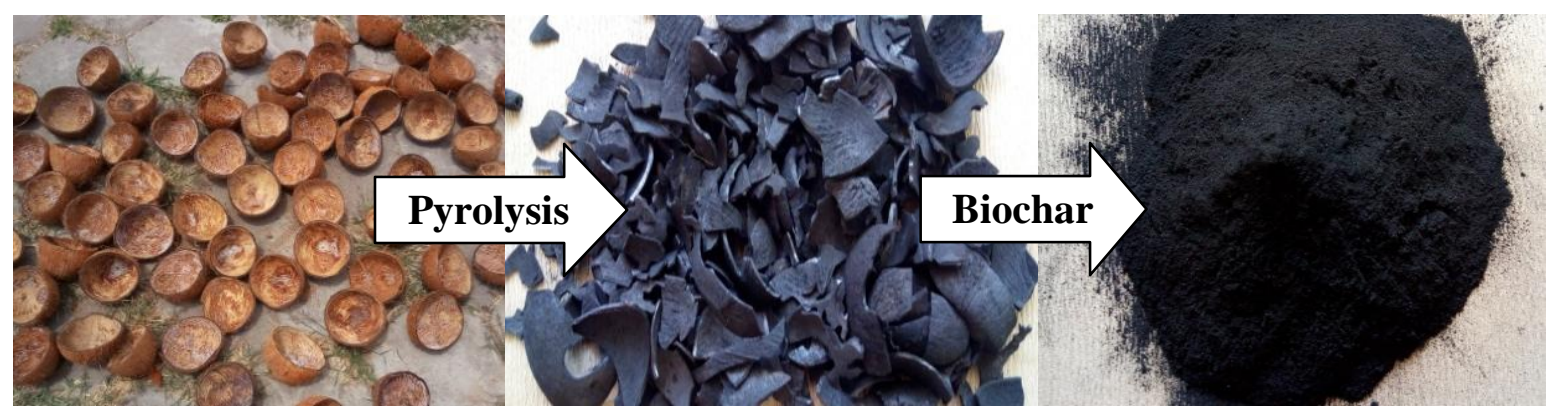

In conclusion, the produced adsorbent carbon is rich in carbon percentage. It can be well utilised for activation to enhance its textural properties, surface area and porosity. The Coconut shells are best alternative against commercial activated carbon because it is accessible and cheap in south Indian states. It can be a beneficial product for the improvement of farming community in marketing sector and stays a perfect part in waste water treatment systems at the industrial level.

\section{Acknowledgement}

The authors are thankful to DST-SERB for providing fund and support in carrying out research work, also thankful to Coconut Research Station, Tamil Nadu Agricultural University, Aliyarnagar and the Department of Environmental Sciences, Tamil Nadu Agricultural University for helping in completion of work.

\section{References}

Ahmedna M, Marshall WE. and Rao RM. (2000).
Granular activated carbons from agricultural by-products: preparation properties and application in cane sugar refining, Bulletin of Louisana state University Agricultural centre, 54.

Bello, S. (2016). Physical properties of coconut shell nanoparticles, (July).

Ekpete, O. A., Harcourt, P., Chemistry, I., \& Harcourt, P. (2011). Preparation and Characterization of Activated Carbon derived from Fluted Pumpkin Stem Waste (Telfairia occidentalis Hook F), 1(3).

Horsfall, M. (2007). Adsorption of Methyl Red by Water-Hyacinth (Eichornia crassipes) Biomass, 4, 2236-2245.

Li, W., Yang, K., Peng, J., Zhang, L., Guo, S., \& Xia, H. (2008). Effects of carbonization temperatures on characteristics of porosity in coconut shell chars and activated carbons derived from carbonized coconut shell chars. Industrial Crops and Products, 28(2), 190198.

Okieimen FE., Okiemen CO. and Wuana RA. (2007). Preparation and characterization of activated carbon from rice husks, J. Chem. Soc., 32, 126-136.

\section{How to cite this article:}

Sangeetha Piriya, R., R.M. Jayabalakrishnan, M. Maheswari and Venkatesan, K. 2019. Preparation and Characterization of Adsorbent Carbon Derived from Cocus nucifera at an Elevated Temperature. Int.J.Curr.Microbiol.App.Sci. 8(05): 1158-1162. doi: https://doi.org/10.20546/ijcmas.2019.805.131 